\title{
Iatrogenic Cushing syndrome and acute adrenal insufficiency due to the association of inhaled corticosteroids and ritonavir
}

Authors: Zubillaga. I, Francés.C, Nicolau.J, Sanchis.P, Homar.F, Fortuny.R, Masmiquel.L

Endocrinology Department. Hospital Son Llátzer, University Institute of Health Science Research ( IUNICS-IdISPA).Palma de Mallorca. Spain

\section{Introduction:}

Ritonavir is a potent inhibitor of the cytochrome P450 enzyme CYP3A4 and is subject to multiple drug-drug interactions. Hepatic metabolism of inhaled corticosteroids (ICS) takes place via cytochrome P450 3A4. Nevertheless, it can be decreased by enzyme inhibitors such as itraconazole or ritonavir, thus leading to an increase in the bioavailability of ICS, specially fluticasone. This can result in an accumulation of the steroid drug and a cushing's syndrome.

$\begin{array}{ll}\text { Hormone } & \text { Results } \\ \text { TSH } & 4,4 \mathrm{uUl} / \mathrm{ml} \\ \text { T4L } & 0,97 \mathrm{ng} / \mathrm{dl} \\ \text { FSH } & 3,11 \mathrm{mUl} / \mathrm{ml} \\ \text { LH } & 0,21 \mathrm{mUl} / \mathrm{ml} \\ \text { 17-beta- } & 17 \mathrm{pg} / \mathrm{ml} \\ \text { estradiol } & \\ \text { Prolactine } & 28,4 \mathrm{ng} / \mathrm{ml} \\ \text { Cortisol } & 3 \mathrm{ug} / \mathrm{dl} \\ \text { ACTH } & 6,7 \mathrm{pg} / \mathrm{ml} \\ \text { DHEAS } & <0,15 \mathrm{mcg} / \mathrm{ml} \\ \text { Insulina } & 10,63 \mathrm{uUl} / \mathrm{ml} \\ \text { IGF-1 } & 190 \mathrm{ng} / \mathrm{ml}\end{array}$

\section{Case Report:}

-We present the case of a 48 year old woman with human immunodeficiency virus (HIV) infection on highly active antiretroviral therapy that included ritonavir. Inhaled fluticasone was added to her medication for the treatment of severe chronic asthma

-Two years latter, she was admitted to the Intensive Care Unit due to massive upper gastrointestinal bleeding secondary to erosive gastritis, which required support with vasoactive drugs for 72 hours.

-However, one week after her admission, the patient started to present hypoglycemia and hypotension $(80 / 50 \mathrm{mmHg})$, accompanied by intense asthenia and weakness of the inferior limbs . Adrenal insufficiency was suspected .

-The Physical exam showed a cushingoid appearance .

-Bloods tests demostrated normal renal, liver functions and electriolytes. Hormone test were as follows: Morning cortisol 3 ug/dl (5-17 ug/dl A.M), Adrenocorticotropic hormone (ACTH) $6.7 \mathrm{pg} / \mathrm{ml}(<46 \mathrm{pg} / \mathrm{ml})$. Prolactin and thyroid hormones were normal.

-A cranial CT focus in the sella turcica was done in order to rule out structural disease (MRI could not be done due to the morbid obesity of the patient) and it was normal .

-Therefore, final diagnosis was iatrogenic Cushing syndrome and an acute adrenal insufficiency due to the association of inhaled corticosteroids with ritonavir

\section{Conclusions:}

This case emphasizes the need for pharmacovigilance when managing patients on complex drug regimens for physicians treating HIV infected patients.

\section{References:}

-Saberi P, Phengrasamy T, Nguyen DP. Inhaled Corticosteroid Use in HIV-positive Individuals taking Protease Inhibitors: a Review of Pharmacokinetics, Case Reports, and Clinical Management. HIV Med. 2013 October ; 14(9): 519-529.

-Blondin MC, Beauregard H, Serri O. Iatrogenic Cushing Syndrome in patients receiving budesonide and itraconazole or ritonavir: two cases and literature review. Endocrine Practice Vol 19 No. 6 November/December 2013.

-Foisy MM, Yakiwchuk EMK, Chiu I, Singh AE. Adrenal suppression and Cushing's syndrome secondary to an interaction between ritonavir and fluticasone: a review of the literature. HIV Medicine (2008), 9, 389-396.

-Vanhorebeek I, Langouche L and Van den Berghe G. Endocrine aspects of acute and prolonged critical illness. Nat Clin Pract Endocrinol Metab. 2006 Jan;2(1):20-31.

-Raaska K, Niemi M, Neuvonen M, Neuvonen PJ, Kivisto KT. Plasma concentrations of inhaled budesonide and its effects on plasma cortisol are increased by the cytochrome P4503A4 inhibitor itraconazole. Clinical Pharmacology and Therapeutics 2002; Volume 72, number 4. 